GEOGRAFICKÝ ČASOPIS / GEOGRAPHICAL JOURNAL 72 (2020) 1, 81-102

DOI: https://doi.org/10.31577/geogrcas.2020.72.1.05

\title{
OWNERSHIP TRANSFORMATION AND FDI AMONG NATIONAL CARRIERS OPERATING ROAD PASSENGER TRANSPORT SERVICES IN THE VISEGRÁD GROUP (V4) COUNTRIES
}

\author{
Zbigniew Taylor*, Ariel Ciechański* \\ * Institute of Geography and Spatial Organisation, Polish Academy of Sciences, \\ Twarda 51/55, 00-818 Warsaw, Poland \\ z.taylor@twarda.pan.pl,ariel@twarda.pan.pl
}

\begin{abstract}
Ownership transformation and FDI among national carriers operating road passenger transport services in the Visegrád Group (V4) countries

The aim of this article is to investigate the changes and derive generalizations concerning the processes related to the ownership transformation and implementation of the foreign direct investment (FDI) in the public interurban bus transport in the Visegrád Group (V4) countries in the years 1989 - 2015. The author's interests focus on the transformation among national road passenger transport companies in Poland (PKS), Czechia (ČSAD) and Slovakia (ČSAD and SAD) and Hungary (Volán). The most important role in the restructuring that has taken place is seen to have been played by various forms of privatisation process (including voucher privatisation, workers' leasing and privatisation with investor participation). A particular role has also been given to foreign direct investment (FDI), first and foremost in the brownfield form (via takeovers). The focus here is on the comprehensive participation of the largest investor (Deutsche Bahn, German state railways), which is active in all four states, albeit via very varied schemes, procedures and means of involvement. Despite the similar initial situation regarding national carriers operating road passenger transport services, each country's transformation process has since assumed its own form, with the result that each now presents a quite different situation. Moreover, this continues to be characterised by fluctuation and changeability. Overall, the results speak against any common approach to, or equal treatment of, the V4 group of post-
\end{abstract} communist countries, given that each now looks like a specific case.

Key words: restructuring, ownership transformation, FDI, bus/coach carriers, transport companies, Visegrád Group (V4)

\section{INTRODUCTION}

Founded in 1991, the Visegrád Group (V4) is a political and cultural alliance of four Central European countries - Czechia, Hungary, Poland and Slovakia - for the purposes of advancing economic, cultural and military cooperation with one another, along with further integration in the EU. In turn, national carriers operating road transport services are understood to be firms created specially by the respective state administrations of these former communist-bloc countries, with a view to nationwide public services in passenger and/or freight traffic by the roads being provided. As a rule, national road carriers have transported passengers between cities, or else been involved in small towns only. In large cities, urban transport has been a matter for separate specific companies that do not form the subject of this paper. Such has been the specificity of the organisation of transport in former communist countries.

The companies in question include Poland's Państwowa Komunikacja Samochodowa (PKS, the State Road Transport Company), and Československá státní 
automobilová doprava (ČSAD) in Czechia and Slovakia prior to 1993. Post-1993, Slovakia had separated carriers in passenger transport by road (SAD, Slovenská autobusová doprava) and in the road carriage of freight (NAD, Nákladná automobilová doprava). Lastly, Hungary has continued to operate enterprises of the Volán Group. In the case of each of these, the research period of relevance to this article is $1990-2018$.

Among the entities referred to, a characteristic feature was what Bennathan et al. (1991) noted in the case of Hungary's aforementioned Volán, i.e. the combining of road passenger and freight traffic within a single enterprise. This is a solution foreign to the market economy, and one that is difficult to reconcile with the competitive organisation of the transport of freight by road. In fact, passenger carriage by road in Hungary resembles that in other CEECs in having been subsidised. Even so, the maintenance of the two kinds of service within one company with joint staff and board has not proved very successful. In a market economy, the survival and development of a road-haulage company is entirely dependent on its being competitive, i.e. able to react immediately to a rapidly changing demand. This denotes management quite different from the kind based around economic calculations engaged in by subsidised entities.

The primary sources for the study of Poland's PKS companies have been the country's Treasury (www.msp.gov.pl) and its National Registry (www.infoveriti.pl). In the case of Czechia, the relevant Registry (Obchodní rejstrík) has again been referred to, by reading annual reports of companies, and analysing ownership changes post-1996 (www.or.justice.cz). Much worse is the situation surrounding Slovak data, as that country's Commercial Registry (Obchodný register Slovenskej republiky) has much less to offer (www.orsr.sk). Data for Hungary in turn derives from the Magyar Nemzeti Vagyonkezelö (Hungarian National Board of Assets) (www.mnvzrt.hu). Despite some differences in what these Registries offer, the information extracted proves fully comparable. Additional information on all the companies has been taken from their respective websites.

The aim of this contribution is to investigate the changes and provide the generalizations concerning the processes related to the ownership transformation and implementation of the foreign direct investment (FDI) in the public interurban bus transport in the Visegrad Group countries in the years 1989 - 2015. The work described in this paper has tracked changes (and looked for generalisations) when it comes to the transformation processes ongoing among national carriers operating road passenger transport services in the V4. From the outset, literature on the transformations in those four states has been reviewed and respective changes in the state bus/coach industry in other European countries followed. Various forms of privatisation are thus discussed against the V4 background. Indeed, due to different legal systems, preferences, priorities and attitudes towards the transformation of transport companies, the countries analysed have varied in a particularly marked way (Taylor and Ciechański 2018). Attention is paid to FDI as a source of capital and innovation, and a new way of managing. Unfortunately, the inflow of FDI into the V4 has been paralleled by an outflow, which must in general be evaluated as a negative phenomenon. Bankruptcies and the accompanying closures of companies are also a negative assessment. Finally, certain conclusions are arrived at regarding the processes involved. 


\section{LITERATURE REVIEW}

Issues of the transformation of transport systems in the CEECs, and especially the processes of privatisation and deregulation, have been amongst the more important research themes in transport geography over the last twenty-five years or so (Hoyle and Knowles 1992 and 1998, Knowles 1993 and Knowles et al. 2008). An example of such research is provided by Poland, in which - for more than a decade now - the processes referred to have gained wide analysis, in relation to various modes and means of transport, including road transport (e.g. Taylor and Ciechański 2007, 2008a, 2008b, 2010a, 2010b and 2018).

Nevertheless, the world literature on the transformation of national carriers involved in transport by road in former communist-bloc countries has proven to be relatively meagre. An interesting study on the history and situation of Hungarian national enterprises at the start of ownership transformation (Jelic and Briston 1999) included road haulage and was prepared for the World Bank by Bennathan et al. (1991). Prileszky (1993 and no data) in turn contributed regarding the regulation of public bus transport in Hungary. For their part, Nelson et al. (1997) outlined the situation of the Volán enterprise in the mid-1990s. Similar papers on national carriers operating road passenger transport services in Czechia and Slovakia have also appeared (e.g. Historie podniku CSAD, no data, Opletal and Ryba 1996, Palda 1997, Olsson 1999 and Taylor and Ciechański 2017), as well as studies relating to the Polish case (e.g. Majewski and Szałucki 1992, Bạkowski 1999, Komornicki 1999, Dyr and Grad 2000, Polewska-Dorozik 2001, Menes 2002 and Grad 2003).

Worldwide, there is much more abundant literature concerning the operations of the bus/coach industry in other European countries like the UK or Sweden, where a free market did arise (Mackie et al. 1995, Simpson 1996, Knowles et al. 2008, for example). A special place in literature publications is devoted to the British Transport Act 1980, which liberalised long-distance connections, and similar 1985 Act which put an end to licences for local bus traffic outside Greater London and the effects of both of these legal acts for the transport market (Mackie et al. 1995, Tyson 1995, White 1995 and 1997, Banister and White 1997 and Knowles et al. 2008). On the other hand Alexandersson et al. (1998) analyse the results of the introduction of competition into Swedish local bus transport, but Aarhaug and Fearnley (2016) present an interesting study on the deregulation of long-distance coach transport in Norway. An interesting review of the deregulation of inter-urban bus transport in nine countries of Europe was provided by van de Velde (2013). Although that review relates mainly to independent carriers involved in express traffic on local markets, their nature is somewhat similar to national companies operating in V4 countries.

By and large, it is quite often the case that bus markets in the EU have not been liberalised. For example, long-distance traffic by coach in Germany was very much regulated up to 2013 (Bataille and Steinmetz, 2013, Augustina et al. 2014). In Spain, the state licenses and controls bus connections (Bataille and Steinmetz 2013), though the market for long-distance bus (coach) traffic in Italy experienced gradual liberalisation, if only as recently as in $2007-2013$ (Beria et al. 2014). 


\section{BASIC CONCEPTS}

Restructuring is seen as a 'radical change in at least one of three dimensions of organisation, that is in the scope of activity, structure of capital, or inner organisation of the entity' (Sapijaszka 1997, p.30). Here, we will above all focus on changes in the structure of the capital of entities analysed which link up directly with the processes of the deregulation and privatisation of transport companies. Since there is a huge amount of world literature on this subject, there is no need to repeat the results and definitions here. Instead, we will focus on the authors' understanding of the basic concepts.

Deregulation of transport should be considered in a wider context, along with the relevant ideology and state policy, the latter most especially in relation to privatisation. Indeed, in the transport context, what is meant here is not merely the sale of state wealth, but also various privatisation initiatives within the public sector, for example involving communalisation or commercialisation. Specifically, the denationalisation of firms can be accompanied by various anti-monopoly ventures that enforce the establishment of conditions providing for competition (Schnell 2001 and Shaw 2001).

Quite a common situation for public monopolies is to be privatised without any prior introduction of changes (with the result being higher sale prices), but at the expense of lowered competitiveness and a loss of combined advantages. Privatisation seeks to raise the level of efficiency and secure greater competitiveness, as its main purpose. Actual competition is treated as the best way of protecting the public interest - as a purpose capable of being achieved by deregulation (Farrington 1985).

While deregulation is sometimes deemed to be accompanied by liberalisation, the differences between the two are not easy to indicate (Teichmann 1995, Bernacki 1996, Gibb et al. 1996). An understanding of the terms as synonymous is not unusual. For example, Bell and Cloke (1990) treat deregulation or liberalisation as the removal or weakening of control in various industries, with the free influence of market forces permitted. For Graham et al. (2008, p. 370), there are some differences between the two (deregulation takes place within a country while liberalisation pertains amongst countries), but often these terms are used interchangeably. Yet others conceive liberalisation as 'a misnomer for re-regulation, the replacement of one set of interventionist rules by another more flexible set' (Graham 1998, p. 88). Likewise, Liberadzki (2007) considers liberalisation as a weakening (rather than a deregulatory abandonment) of restrictions 'with the purpose of enhancing towards greater efficiency in the functioning of the market. A deregulated market means no regulation, while a liberalised market is regulated but in a way that enables many subjects to exist, and allows for entries on to and exits from the market' (Liberadzki 2007, p. 39). In practice, the term deregulation is used in Englishspeaking countries, while liberalisation is more common in continental Europe (e.g. in France), and in EU legislation. In the remaining part of the paper, we will use the term deregulation, as the analysed phenomena and processes relate to the internal situation in the countries under review, rather than the international situation.

For the purpose of this paper, account has been taken of the following categories of processes when it comes to ownership transformation among national carriers operating road passenger transport services: 
(1) Commercialisation taking place in all V4 countries. In some of them it has been the first step towards further privatisation (as in Czechia and Slovakia, above all, but partly also in Poland). In Hungary, but also partly in Poland, this has in fact been the last step in ownership transformation (sometimes before bankruptcy). Moreover, in Poland, commercialisation has sometimes been treated as a further step towards communalisation;

(2) Communalisation - a process occurring in Poland only, denoting a transfer of a commercialised state enterprise to local, county-level or regional governments, or to companies directly dependent on them;

(3) Privatisation:

a) voucher privatisation - taking place in Czechia only, and related to all former state firms being directed to a universal programme. Poland has passed through a somewhat similar programme of universal privatisation, though this did not in fact encompass PKS entities;

b) workers' privatisation - this form only received approval in Poland, and has applied to the sale of whole enterprises. In the remaining countries (besides Hungary), workers' participation has also taken place, especially with the involvement of managerial staff in the processes of firm privatisation, but the principles involved have been general, rather than specific;

c) privatisation with the participation of a foreign investor - this form has taken place in all countries of the V4 except Hungary. In Poland, the dominant form has been direct purchase from the State Treasury. In the case of Czechia and Slovakia there have been mixed variants, i.e. buyouts directly from the state, or indirectly from domestic and foreign investors;

d) privatisation with the participation of a domestic investor. It is possible to identify branch investors - other domestic companies operating in the transport of passengers by road, but also other entities carrying on such activity in Czechia, Poland and Slovakia. Also included in this group are companies set up by workers and managerial staff (employee privatisation) with the purpose of purchase on general (not privileged) principles. There have also been non-branch investors purchasing companies mainly by way of investment funds (in Poland, Czechia and Slovakia) and real-estate agencies (Poland);

(4) Consolidation of enterprises, usually as a process preceding their commercialisation (in Poland, Slovakia and Hungary), or leading towards the simplification of means of management (Poland and Czechia);

(5) Closure without transformation - as a characteristic for Poland, first and foremost.

\section{COMMERCIALISATION}

Over many years, in all the countries researched, commercialisation has been a basic form of ownership transformation where national bus companies are concerned. It is understood as the creation of a limited liability or joint-stock company with an exclusive or nearly-entire share for the state, and on the basis of an existing state firm. The four main procedures to be distinguished are: 
- commercialisation with a view to voucher privatisation taking place - characteristic for Czechia;

- commercialisation with a view to further sale to a domestic or foreign investor - occurring mainly in Poland and Slovakia;

- commercialisation as a final form in ownership transformation - mainly in Poland and Hungary;

- commercialisation as a first step towards communalisation - noted in Poland only.

The most common form of ownership transformation of Poland's PKS enterprises has been their commercialisation - a process and term actually emerging as having more a legal than an economic or market-related meaning (Szałucki 2003). A transformation in so-called single-personality Treasury companies started in 1997, and in each subsequent year some 8-10 enterprises were commercialised on average. Through to the end of the commercialisation processes in 2012, some 92 companies had been transformed in this way, or over half the total. However, this number relates to the cumulated number of companies, since, in parallel with the creation of new entities, processes of closure and further transformation occurred.

Since 2005, processes entailing the closedown of least-effective or deficitaccruing companies have occurred. Another reason for the decrease in the numbers of single-personality Treasury companies reflects ongoing processes of privatisation and communalisation. Because of privatisation, communalisation and the relatively numerous bankruptcies, as of 2015 , the Treasury owned just eight companies functioning in passenger transport. In fact, this number continues to decrease.

In the case of Czechia, commercialisation has been practically a one-step process preceding voucher privatisation (kuponovka), which is described in more detail later on. In Slovakia, the idea of privatisation of entities came back as late as in 1999. Hence, in 2000, a new concept for the transformation and privatisation of SAD state enterprises was prepared, and from 2001 a process of commercialisation was initiated which lasted through until the middle of the next year (www.kamin.sk; www.sadmi.sk; Koncepcia transformácie..., no data).

A quite different process is the commercialisation of the national bus carrier in Hungary. Above all, and continuing through until the present day, this is the last process required to achieve ownership transformation of the Volán companies. Unlike in other countries of the region, it is here possible to refer to waves of simultaneous transformation. Commercialisation of 28 Volán passenger transport companies took place in December 1992. A minority of the shares (usually several per cent) came to the employees of the transformed entities. In early 1998, four companies ceased to exist on account of their consolidation with two others. The locations of companies are now more or less concordant with the country's administrative division. In 2012, new regional companies were established with a scope corresponding to EU units of territorial administration at the NUTS-2 level. It is into these that the 24 previously-existing regional companies have been incorporated, and this remains the current situation. In some cases, the consolidation has not ended the practice of a symbolic number of shares remaining in the hands of employees. 


\section{COMMUNALISATION}

As privatisation of Poland's PKS companies did not take place in a manner the authorities could either have wished for or expected. Another means of ownership transformation was needed urgently. An obvious partner seemed to be local authorities interested in providing proper transport services to the inhabitants of their respective regions. At the outset, local authorities were more involved in projects involving worker leasing (i.e. employee privatisation), than in buyouts of local carriers.

As the PKS carriers quite often provided services in just one or two counties, obvious partners for them might have been authorities at county level in Poland. However, the situation has been far more complicated in reality. Communalisation or a transfer of shares in national carriers of bus transport to local or regional authorities has only been a typical phenomenon in the case of Poland. The processes started in 2008 with a view to single-personality Treasury companies (in which the shares range between 85 and $100 \%$ ) being transferred to local or regional authorities. There was a rapid increase in the number of communalised companies around 2010 , followed by a decrease. In total, 48 enterprises were communalised, with 16 transferred to regional (voivodship) authorities, 23 to county-level (powiat) authorities, six to local authorities (gminas) in urban areas and three to unions of gminas (of which one - in the city of Stupsk - broke down, with the effect that the shares returned to the respective individual gminas).

Unfortunately, communalisation has failed to match the hopes held out for it. The trend leading towards closures of PKS companies has not been fully finished, as can be seen by reference to the example of the Małopolska region; while some companies in the Kujawsko-Pomorskie voivodship have been consolidated into just a single one. Fortunately, some communalised companies in various regions have gone on to be privatised.

\section{PRIVATISATION}

Processes of privatisation in passenger transport entities were first noted in Czechia, where a majority of them were privatised in the early 1990s, mainly within the voucher privatisation scheme. Later on, only a few were transformed in a similar way. Indeed, after 2005 no privatisations at all took place. In Slovakia, privatisation started about a decade later, and additionally involved prior consolidation of the SAD enterprises. Even more recent processes of privatisation on a wider scale have occurred in Poland, though the first more or less coincided with similar activity in Czechia, if applied, not to whole enterprises, but to the parts involved in passenger transport only. Nevertheless, most buyouts took place in the 2000s, while also continuing after 2010. An aspect characteristic for Poland is the way a majority of enterprises were merely closed down, without any attempts at privatisation. Though many entities in Slovakia were also merged, this was still connected with a process of consolidation designed to strengthen entities in advance of their planned privatisation. In turn, while the Hungarians have likewise consolidated their Volán enterprises, they have not decided on their privatisation thus far. 


\section{Voucher privatisation}

A privatisation procedure characteristic for Czechia alone has been voucher privatisation. The work detailed here has looked into 39 CSAD enterprises (Fig. 1). Of these, an absolute majority (37) are found to have been involved in passenger, or mixed passenger and freight, traffic. The voucher privatisation of ČSAD started in 1992, when 14 enterprises were transformed into joint-stock companies, and later on directed to the programme of universal privatisation. In 1993, a similar method was used to achieve the privatisation of a further 7 entities, while the whole process terminating just one year later, with transformation of the last 18 enterprises (Taylor and Ciechański 2017).

\section{Worker privatisation}

In the case of Poland, a characteristic phenomenon has been the so-called worker privatisation, which is actually a form of leasing by employees. Poland has been the only country to modify its legal system to approve this form of transformation, which ultimately concerned 42 entities over the years 1997 - 2009 (Fig. 1). However, the real boom in this kind of activity characterises the briefer $2000-2004$ period (with $8-9$ entities annually then transformed).

Since the processes of worker privatisation have come to an end, or at least slowed down greatly, a conclusion regarding successful transformation can probably be drawn. However, it needs to be recalled that - over the years - the ownership structure involved here was able to change to one in which more and more shares belong to strategic investors. Indeed, it has been quite typical for the staff of given enterprises to actually be supported by external investors. In some cases the latter have been the authorities of the locality serviced by the given transport company. Alternatively, the role of an external investor has sometimes been played by other PKS companies already privatised in a similar way.

\section{Privatisation with the participation of a foreign investor}

Among the cases of FDI in non-urban bus transport, an absolute majority have been brownfield investments (takeovers) directed at former national carriers operating road passenger transport services. A second type of investment has been focused on private companies, with possible competition generated, or locations in areas adjacent to companies already owned. This type of takeover confined to Czechia has been pursued by companies whose capital has later been connected with German state railways DB (Fig. 2). A process of a third type involves greenfield investment, though this has taken place much more seldom, as with the then Polski Express (owned by the UK National Express Group), or Polskibus.com (Souter Investments) both active in Poland. Having a similar nature of greenfield FDI, although with a much different scope, has been the investment of the Czech railway and bus carrier Student Agency in Czechia and their subsidiary RegioJet in Slovakia.

One of the most common and desired forms of privatisation in the V4 countries has been the buyout of the entire or the majority stake in an enterprise by a foreign investor. In the case of Poland, direct investment has occurred first and foremost. 


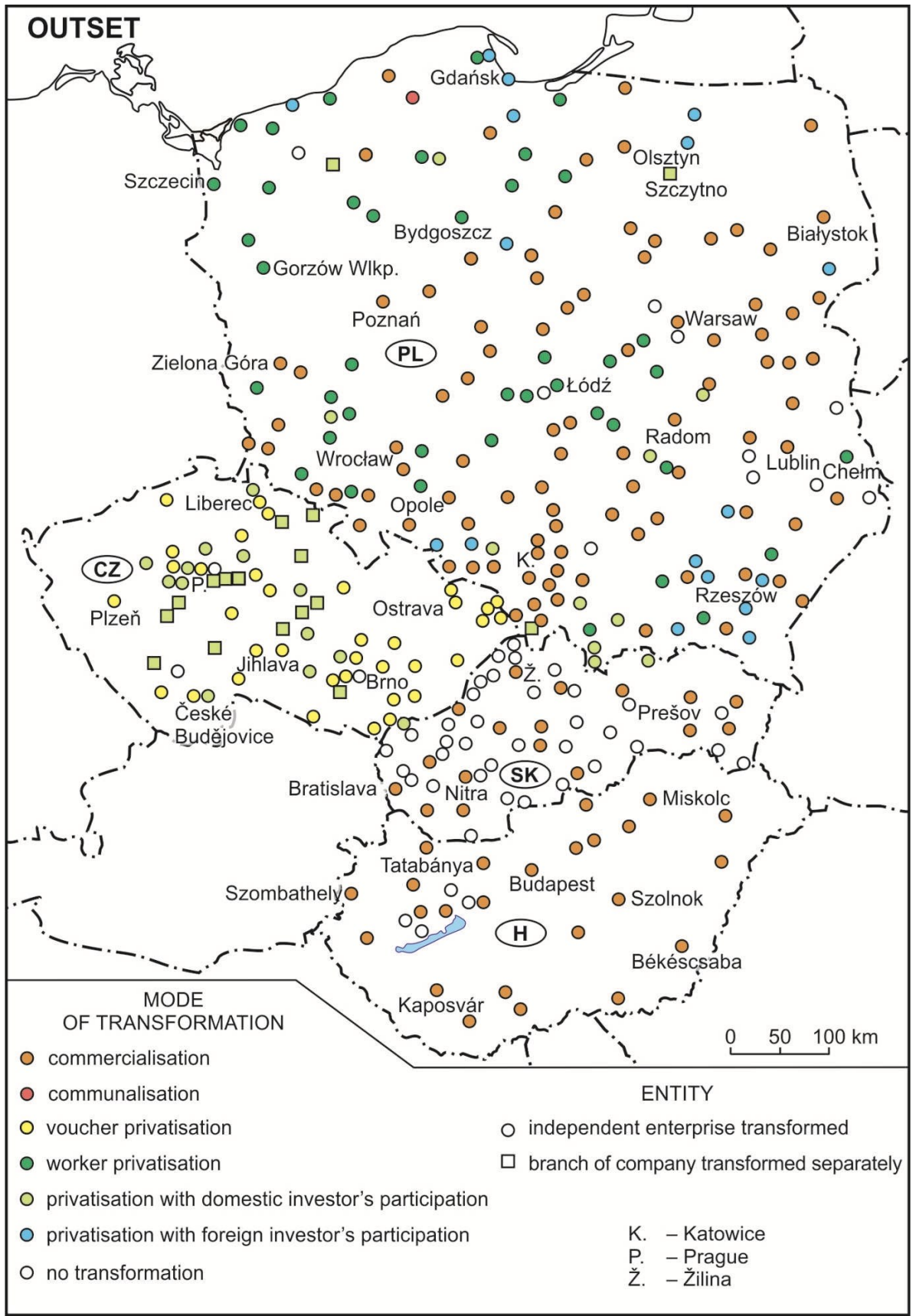

Fig. 1. Initial form of ownership transformation in enterprises involved in the transport of passengers or mixed passenger/freight traffic by road

Source: Authors' own elaboration. 


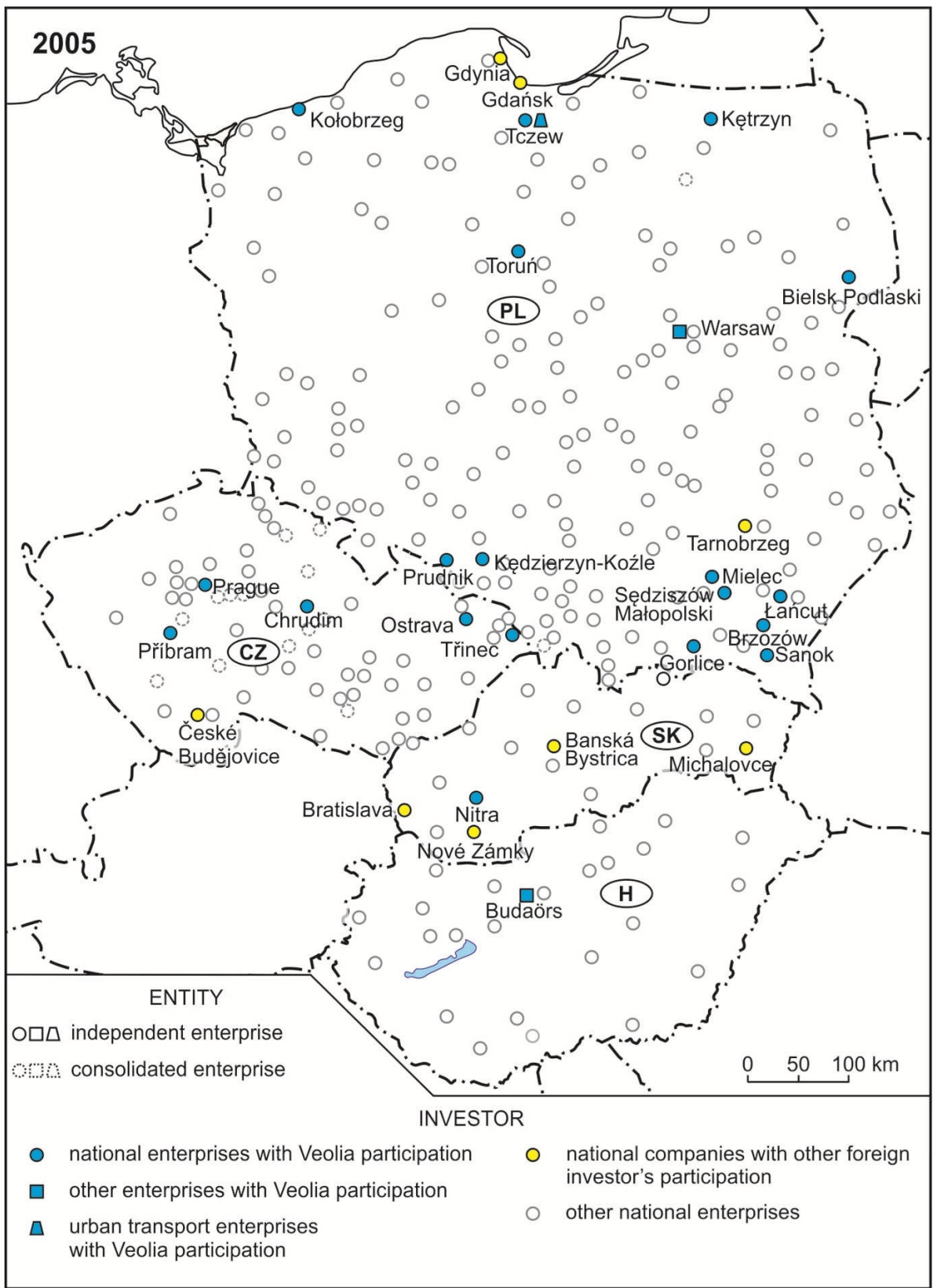

Fig. 2. FDI in national road passenger transport enterprises as of 2005 Source: Authors' own elaboration.

In the early 2000s, the main foreign investor in Poland was the present-day Arriva Bus Transport Polska. They bought 14 PKS enterprises in total. However, it 
was in 1998 that the predecessor firm appeared on the Polish market, under the name CGEA Transport Poland. Later on the firm went by the name Connex Polska, only to become Veolia Transport Polska in the years 2006 - 2013. The first investment of Connex in Poland was a buyout of shares in the Rapid Bus firm, providing passenger carriage in urban and suburban areas of the capital city. In 2001, the investor purchased majority shares in two enterprises in SE Poland and in urban transport in the town of Tczew. Next, three other entities in southern Poland were taken over, while in 2004 and 2005, the Connex Polska Group purchased enterprises in various parts of the country. The last takeovers took place in 2007. Since the late $2000 \mathrm{~s}$, it has been possible to observe a gradual consolidation of companies, first into six regional ones, and then in 2010 into one nationwide company with its seat in Torun. Among these, the only PKS company not to have been purchased directly from the Treasury was the former PKS Gdynia, which was bought from the British Dunn Line by Veolia, and next consolidated within the main company. In turn, the consolidation in SE Poland can be linked to a declining demand for carriage, and changes in the management of a much larger company. In 2013, as a result of the purchase of the Veolia Transport Central Europe by the Arriva company (an affiliate of DB railways), a carrier came into existence that is today called Arriva Bus Transport Polska.

As in Poland, and also in the case of Czechia, Arriva is currently the largest foreign investor in the bus industry. Its process of investment - then as the Connex company - started in 1999 with the purchase of CSAD Bus Ostrava, separated from the rest of carrier. In the years $2001-2004$, Connex purchased several other bus operators, also as an absolute majority separated from larger multi-functional companies. However, in 2008 (coincidently on the occasion of the change in the owner's name from Connex to Veolia), these companies were consolidated into Veolia Transport Praha and Veolia Transport Morava.

These in fact represent the most recent purchases of ČSAD entities. Investments by Connex, and later by Veolia, has thus focused on several regions. It may be supposed that a result of this strategy first pursued in 2008 was a process not met with in Poland, namely a purchase of private companies not in public ownership but located in the vicinity of previously-purchased ČSAD entities. Thus, unlike in Poland, the presence there of the DB holding and the Arriva company has not been confined to entities purchased from the Treasury. Before the Veolia takeovers, buyouts were also accomplished by way of Arriva holding Česká republika. In this way, Arriva has since 2006 been the owner of Transcentrum bus - a private bus operator in the environs of the city of Mladá Boleslav (www.arriva.cz). The companies of the DB Group also include Probo Bus, given that this was purchased in 2009, by an affiliate of Dutch state railways NS called Abellio Transport CZ Holding BV, only to be taken over subsequently by the DB holding.

In the case of Slovakia what is involved is interest shown - and purchases made - by Arriva, by way of a Hungarian affiliate called Eurobus Invest of Budapest, which purchased SAD Nové Zámky directly, before making an indirect purchase of SAD Michalovce. In 2005, the buyer of this investor became a part of the then British Arriva Group. A purchase by the later Veolia - which bought SAD Nitra from the Slovak firm KMV Bus, was also made indirectly. SAD Trnava came into the ownership of the British investment firm Sabre Invest, only to join Liorbus of Ružomberok in being purchased indirectly in 2015 (via a buyout of the parent companies), by the Slovak Arriva company. 


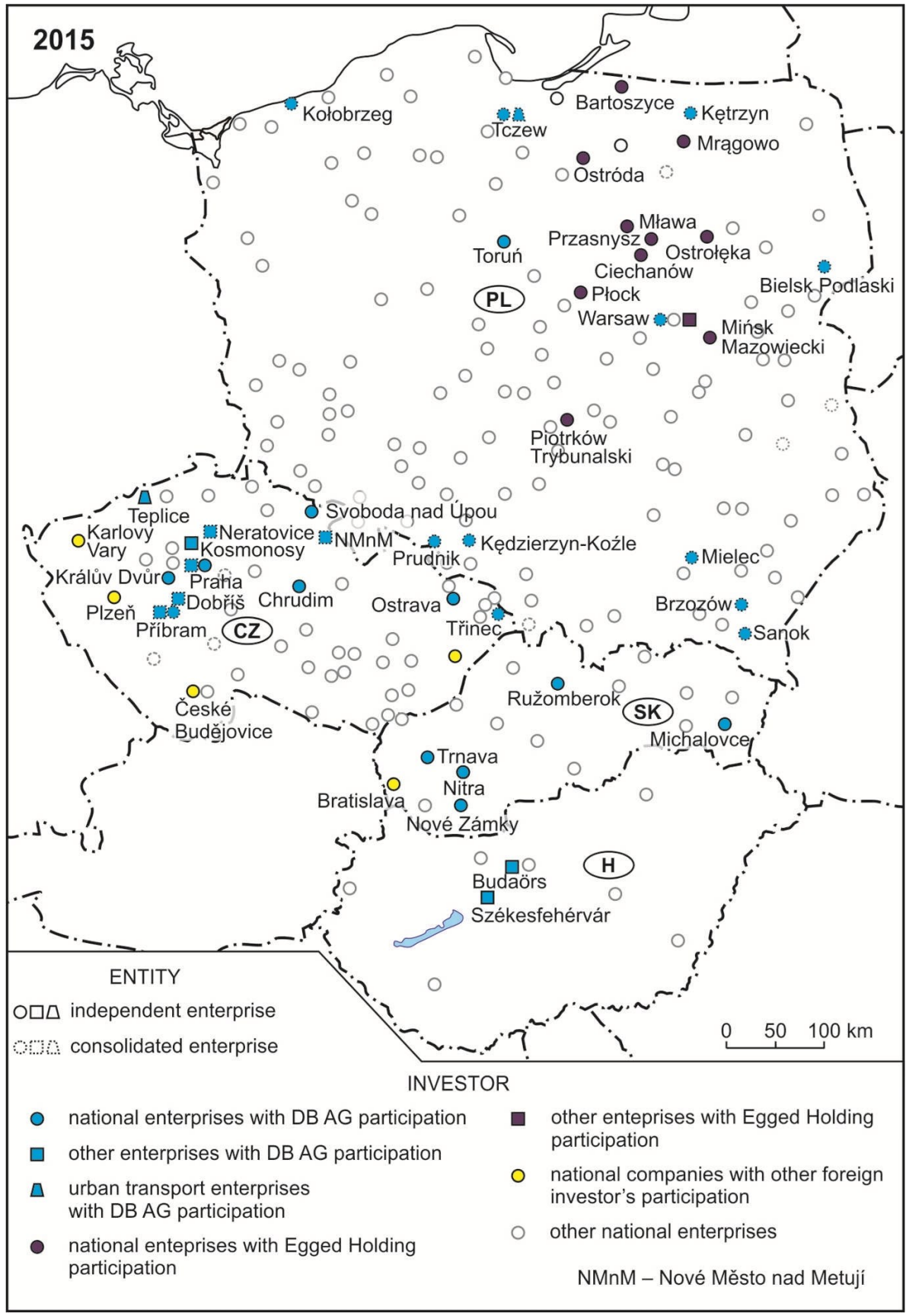

Fig. 3. FDI in national road passenger transport enterprises as of 2015 Source: Authors' own elaboration. 
In Hungary, Arriva and its predecessors could not take part in the privatisation of national bus entities. Nevertheless, through a buyout of Eurobus in 2008, Veolia came into indirect possession of Hungary's largest private bus carrier, VTTransman.

It might be anticipated that the experiences with Veolia in Poland have been so unsatisfactory that the processes of FDI in PKS entities have come to be suppressed permanently. In fact, however, in 2009, the Israeli Egged Holding (the largest private bus operator in public urban transport in Poland) commenced with its involvement in PKS entities. Subsequent (2010) takeovers were then achieved by way of the affiliate Mobilis, which has engaged in bus carriage in large urban centres on behalf of their local authorities. The activity of Mobilis originated from the second part of the Rapid Bus company already referred to.

Egged Holding is an affiliate of the Israeli firm Egged founded in 1933, and is currently the largest bus carrier in this country. Mobilis represented Egged's first investment in Poland. In 2010, Mobilis purchased $85 \%$ of the shares in companies from the Mazowsze region, buying practically a majority of the Treasury-owned firms put up for sale. Only three companies have in fact gone unpurchased. In 2011, the Israeli firm bought two PKS entities in the Warmia-Mazury region, and a year later - one in central Poland. An interesting circumstance would then be that the Egged Holding, a purchaser of 10 PKS companies altogether, has no presence whatever in the remaining V4 countries (Fig. 3).

Veolia has not been the only foreign investor interested in ČSAD enterprises. In 2003, Austrian bus carrier ÖBB Postbus (an affiliate of Austrian state railways) purchased a company called ČSAD Autobusy České Budějovice. Thus far, that represents the only investment by ÖBB Postbus in Czechia. In turn, the owner of BusLine, a company called ZVV Property Investment (Cze) is most probably a Czech firm transferred to one of the tax havens. To the best of the authors' knowledge, this is the only such situation in Czechia.

Where the PKS companies are concerned, there are few examples of FDI apart from the aforementioned cases involving Veolia and Mobilis. Orbis Transport (indirectly dependent on French-Dutch capital) has made purchases of the PKS companies in Tarnobrzeg and Gdańsk and has specialised in international coach traffic. Because of the bankruptcy of its parent company, Orbis Travel has been closed down, with the shares in PKS companies therefore sold on to new buyers. These have not been active at all in other V4 countries.

A characteristic feature of the Slovak privatisation process has been a substantial share of foreign capital (in c. 1/3 of privatised companies). This has mainly originated in adjoining countries, such as Czechia or Hungary.

Privatisation with the participation of a domestic investor

In Poland, it is only with some difficulty that the privatisation of the PKS enterprises has taken place. Indeed, before Connex commenced with its activity, certain domestic investors appeared, showing an interest in the buyout of one or two enterprises, but the scale of resulting takeovers has been relatively small. As late as in 2001, a consultancy firm involved in advisory services, teaching and research appeared to create an impulse to a wave of privatisation. Among buyers, it is possible 
to distinguish several main groups, i.e. branch investors (including other PKS companies and managerial staff of companies not involved in worker privatisations), capital-market companies and real-estate agencies.

Domestic investors likewise include branch investors, operating either directly, or indirectly by way of the purchase of affiliates. The passage of time will presumably entail a consolidation of the relevant branches and companies respectively.

The process achieving the direct privatisation of ČSAD entities is as important as the means of ownership transformation, such as voucher privatisation. The two forms distinguishable are: the direct sale of a state enterprise in its entirety; and the buyout of separated branches of a closed-down state enterprise. In a majority of cases, privatisation has meant a takeover of property of a former entity or branch (rolling stock, depot, etc.) and further engagement in activity under the buyer's name. Overall, 11 entities have been privatised by direct sale, with two among these sold twice (as the buyer did not meet requirements). The process started relatively early, in fact simultaneously with voucher privatisation.

Privatisation of the enterprises and branches of ČSAD has frequently been a prelude to further ownership transformation. Three processes distinguishable are: (1) the creation of affiliates with a view to one activity being engaged in; (2) the sale of a ČSAD enterprise or an affiliate to a foreign investor; (3) the purchase of one predominately privatised company by another. A leader among affiliates has been ČSAD Ostrava, which founded three new entities in the late 1990s. However, in the years $2002-2007$, something similar happened to several other companies.

It is also quite typical for a company to be divided in line with changes in the administrative division of the country (with consequent financial problems relating to the accounting process between local authorities). Closures of existing companies and the creation of new ones have also given rise to further changes relating to both the number of entities and their structure.

In Czechia, the most important domestic investor in ČSAD companies has become the Kratochvíl family, which in 1994 purchased ČSAD Jihlava (ICOM Transport since 1996). Later on, ICOM Transport became the main investor in six other companies, some of which have been consolidated. ICOM is not alone in investing in similar bus carriers, though the scale has otherwise been much smaller.

In 1995, on the basis of SAD regional units, some 52 enterprises were created in Slovakia, only to be consolidated into 17 larger firms in 1999. In just two of these has another means of transformation taken place, i.e. the takeover of enterprises by employees, or with greater participation of managerial staff. Via direct privatisation, investors might gradually buy up the shares in a company. However, the remaining bloc of $34 \%$ shares then had to be transferred to regional or local authorities (www.kamin.sk; www.sadmi.sk; Koncepcia transformácie..., no data).

A majority of entities were commercialised in the 2000s. Out of 17 privatised companies, 16 were active in 2015. Only SAD Banská Bystrica ceased its involvement in carriage, confining its involvement to the running of its bus station. In two companies, new buyers have been entities taken over by their managerial staff. In several other cases, companies have been bought by natural persons. Other investments made by real estate agencies are also to be noted in Slovakia and seem to resemble cases in Poland. 


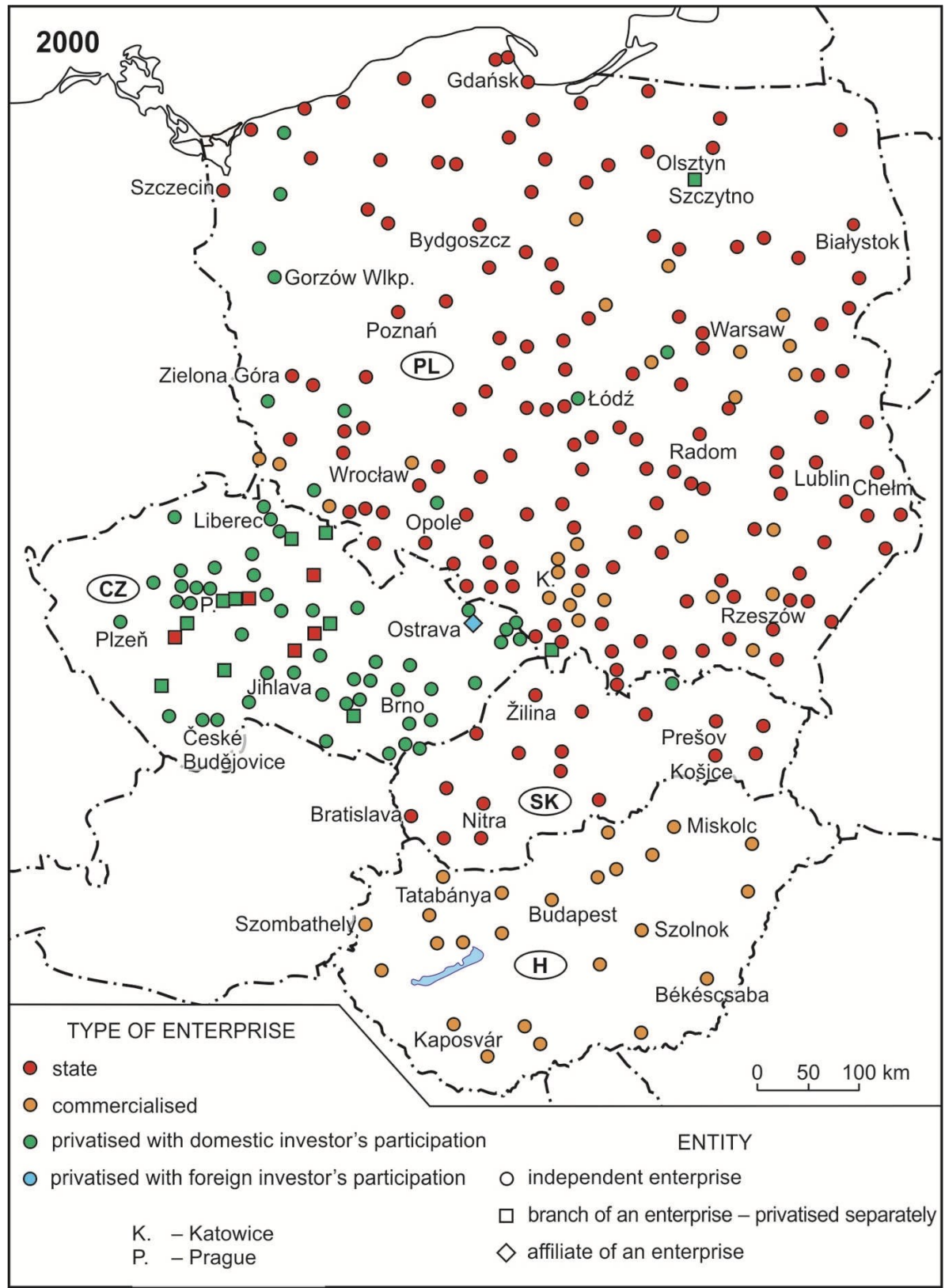

Fig. 4. Enterprises involved in passenger and mixed passenger/freight traffic by road, as of 2000

Source: Authors' own elaboration. 


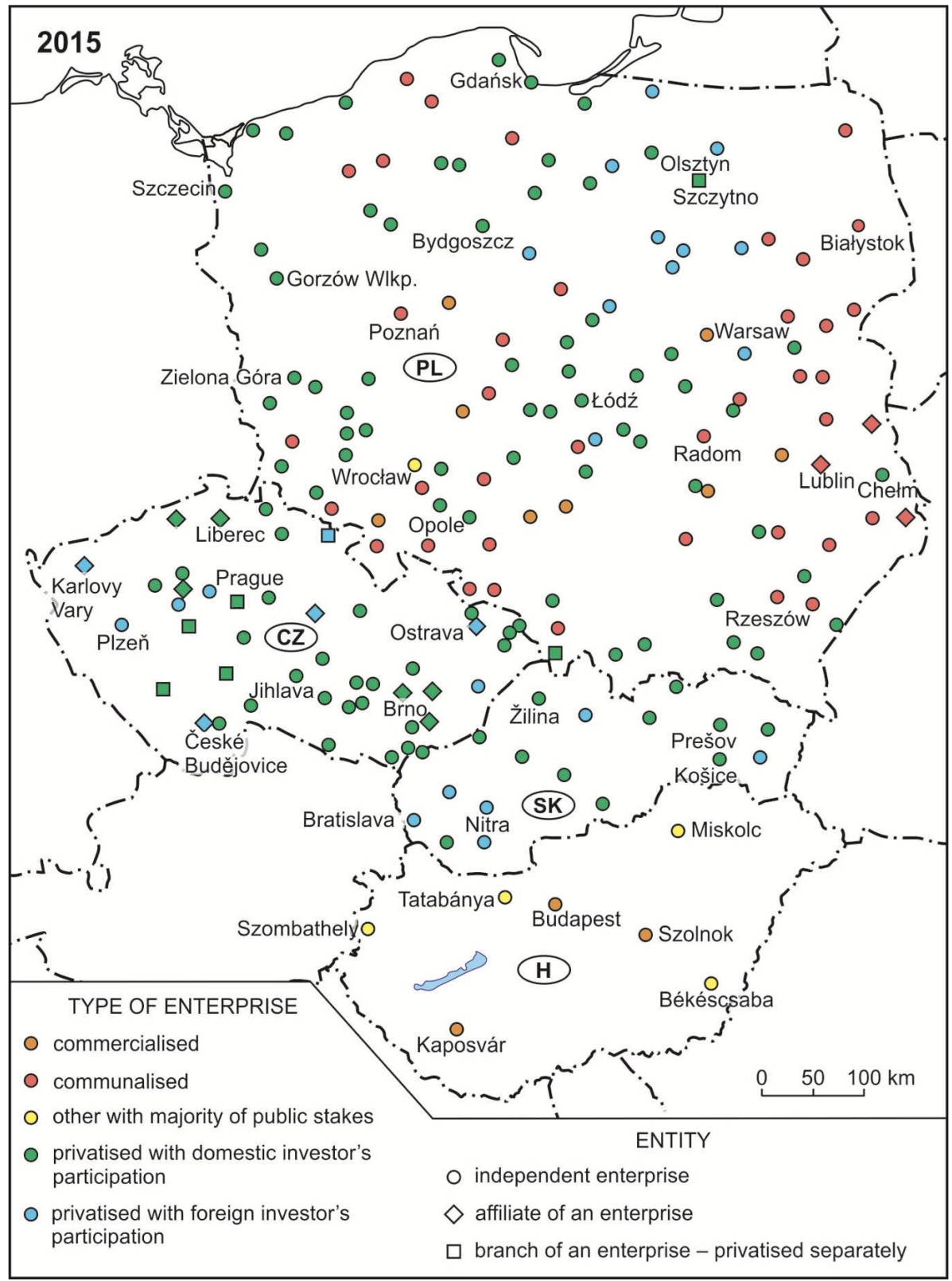

Fig. 5. Enterprises involved in passenger and mixed passenger/freight traffic by road, as of 2015

Source: Authors' own elaboration. 


\section{DISCUSSION AND CONCLUSIONS}

After 10 years of systemic transformation in V4, in the year 2000 it was still possible to observe absolute domination of the public sector (Fig. 4), especially when it came to the state enterprises typical for Poland and Slovakia. By the year 2015 (Fig. 5), the situation was quite different: almost all state enterprises had disappeared, though this did not mean full success of the privatisation processes.

Direct privatisation has been relatively widespread in the V4 countries (except Hungary - Fig. 4 and Fig. 5). The undoubted leader in the privatisation of the intercity bus transport is Czechia, which started (Fig. 4) and completed processes earliest (Fig. 5) and with the greatest success. Because of the country-specific programme of universal voucher privatisation it had already pursued, this country as of 2000 was already characterised by a high share of private ownership.

Where domestic investors are involved, the situation is more complex. Some buyers are branch investors, in part of other previously privatised national carriers. Sometimes these are competitive companies providing services or originating from other regions of the country. There is also (mainly in Poland) a relatively large group of investors not linked to the transport market but originating from the financial and real estate sectors. These groups can be aggressive, especially when a carrier owns attractive assets such as land in urban areas, very often in the heart of the cities.

Equally, in all V4 states we can identify in the year 2000 just one bus company already sold to a foreign investor (ČSAD Ostrava - Fig. 4). By the year 2015 (Fig. 5), the situation was quite different. Where FDI is concerned, there are more major differences among them, with branch investors dominating. An overwhelming role has been played by Germany's Deutsche Bahn, above all by way of the companies of the Arriva Group. It should be recalled that the present ownership structure reflects investment processes carried on for many years by entities of which Arriva is a legal successor, mainly Veolia Transport companies. The remaining foreign entities have invested in single countries, on a wider scale in Poland or in Czechia in isolated cases. Here are also almost no flows of capital passing from national road carriers to neighbouring countries.

Before the year 2000 only a few private companies in Poland had appeared by way of workers' participation (Fig. 4). This kind of ownership transformation was one (rather successful) of the two processes which have been unique and happened in Poland only (Fig. 5).

While Czechia and Slovakia had actually managed full privatisation of their companies, Poland's situation as of 2015 was characterised by a majority of entities privatised, although with quite a number remaining in public ownership. In 2015 companies with exclusive or near-entire share ownership in state hands still dominated in Hungary.

In all the countries studied, the processes of privatisation ensured that, as of 2015 (Fig. 5), private companies were usually active on the market much more often and for a longer time than those in public ownership. Much greater changes were seen in Poland, where the 15-year long period brought a radical decline in the number of former PKS companies. It is the Polish market for passenger carriage by road that has been subject of the strongest liberalisation, not only among V4 countries, but also when the comparison is made with many countries of the 'older' EU. 
In the view of the authors, this has been a mistaken approach having major social and economic consequences. For example, competition on the market was not introduced with a simultaneous provision of socially-motivated services in sparsely populated and less-developed areas of the country and some parts of the country are no longer serviced by bus transport at all.

Commercialisation has been one of the most common processes of transformation which took place in all four V4 countries. Furthermore, it is not actually very homogeneous. In Czechia it has represented one of the stages in voucher privatisation, while in Slovakia and partly in Poland it has been a step towards further sales or communalisation (in Poland). Indeed, in Hungary it has thus far been the only process. A similar situation applies to the Polish entities which maintain this ineffective form of ownership or have gone bankrupt while still enjoying the status of single-personality Treasury companies.

The course followed as companies have been consolidated has also differed markedly, since the reasons for consolidation sometimes fail to relate to privatisation as the main outcome. Quite often consolidation has been linked with job retention, with a transfer of the profits from a stronger company to a weaker one in order to save it. Other factors connected to ease of management by local or regional authorities of one stronger company as opposed to numerous smaller units. Moreover, a new private owner (sometimes foreign) can organise a company as desired, by way of exclusive right. Last but not least, tremendous growth in private motoring in V4 countries post-1990 has greatly truncated the potential market for carriage, hence the need for some consolidation from the investors point of view.

The communalisation of former state bus companies emerged as a Polish speciality and applied widely but ended in failure and many companies disappeared from the market. For example, in Czechia, it was only possible to find a minority share of local authorities in privatised transport companies.

\section{REFERENCES}

AARHAUG, J., FEARNLEY, N. (2016). Deregulation of the Norwegian long distance express coach market. Transport Policy, 46, 1-6. DOI: https://doi.org/10.1016/ j.tranpol.2015.11.004

ALEXANDERSSON, G., HULTÉN, S., FÖLSTER, S. (1998). The effects of competition in Swedish local bus services. Journal of Transport Economics and Policy, 32 (2), 203-219.

AUGUSTINA, K., GERIKEB, R., MARTINEZ SANCHEZ, M. J., AYALAC, C. (2014). Analysis of intercity bus markets on long distances in an established and a young market: The example of the U.S. and Germany. Research in Transportation Economics, 48, 245-254.

BANISTER, D., WHITE, P. R. (1997). Deregulation of buses in Great Britain: Editorial suggestions for further reading. Transport Reviews, 17 (1), 31-35.

BATAILLE, M., STEINMETZ, A. (2013). Intermodal competition on some routes in transportation networks: The case of inter urban buses and railways, [Online], Available: www.econstor.eu/dspace/bitstream/10419/68230/1/734359969.pdf [Accessed 15 February 2016].

BĄKOWSKI, W. (1999). Perspektywy przedsiębiorstw PKS w nowych warunkach administracyjnych. Przeglad Komunikacyjny, 3, 1-4. 
BELL, P., CLOKE, P. (1990). Concepts of privatization and deregulation. In: Bell P., Cloke, P. eds. Deregulation and transport. Market forces in the modern world. London (David Fulton Publishers), pp. 3-27.

BENNATHAN, E., GUTMAN, G., THOMPSON, L. (1991). Reforming and privatizing Hungary's road haulage. Working Papers, 790. Washington DC (World Bank).

BERIA, P., GRIMALDI, R., DEBERNARDI, A., FERRARA, E., LAURINO, A. (2014). Spatial and scenario analyses of long distance coach transport in Italy, [Online], Available: https://mpra.ub.uni-muenchen.de/54739/1/MPRA_paper_54739.pdf [Accessed 2 February 2016].

BERNACKI, D. (1996). Poszukiwanie racjonalnych struktur w transporcie. In: Brdulak H. ed. Trans'95. Wspólna Europa. Szanse i zagrożenia dla transportu. Podsumowanie. Warszawa (SGH), pp. 35-36.

DYR, T., GRAD, B. (2000). Prywatyzacja przedsiębiorstw PKS jako czynnik rozwoju transportu w województwie mazowieckim. In: Transport $w$ rozwoju regionów. Zeszyty Naukowo-Techniczne Oddziału Stowarzyszenia Inżynierów i Techników Komunikacji, Kraków, pp. 255-267.

FARRINGTON, J. H. (1985). Transport geography and policy: Deregulation and privatization. Transactions of the Institute of British Geographers NS, 10 (1), 109-119.

GIBB, R., LOWNDES, T., CHARLTON, C. (1996). The privatization of British Rail. Applied Geography, 16 (1), 35-51.

GRAD, B. (2003). Prywatyzacja w regionalnym pasażerskim transporcie samochodowym czynnikiem konsolidacji rynku usług transportowych. In: Dydkowski, G., Tomanek R. eds., Liberalizacja transportu $w$ warunkach transformacji gospodarczej. Prace Naukowe Akademii Ekonomicznej im. Karola Adamieckiego w Katowicach, Katowice, pp. 59-72.

GRAHAM, A., PAPATHEODOROU, A., FORSYTH, P. eds., 2008. Aviation and tourism. Implications for leisure travel. Aldershot-Burlington (Ashgate).

GRAHAM, B. (1998). Liberalization, regional economic development and the geography of demand for air transport in the European Union. Journal of Transport Geography, 6 (2), 87-104.

Historie podniku ČSAD (no data), [Online], Available: www.liaznavzdy.cz/ČSAD.php [Accessed: 25 October 2012].

HOYLE, B., KNOWLES, R. eds. (1992). Modern transport geography. London-New York (Belhaven Press).

HOYLE, B., KNOWLES, R. eds. (1998). Modern transport geography, 2nd edn. Chichester-New York-Weinheim-Brisbaine-Singapore-Toronto (Wiley).

JELIC, R., BRISTON, R. (1999). Hungarian privatisation strategy and financial performance of privatised companies. Journal of Business Finance \& Accounting, 26 (9-10), 1319-1357.

KNOWLES, R. (1993). Research agendas in transport geography for the 1990s. Journal of Transport Geography, 1 (1), 3-11.

KNOWLES, R., SHAW, J., DOCHERTY, I. eds. (2008). Transport geographies. Mobilities, flows and spaces. Malden-Oxford-Victoria (Blackwell Publishing).

KOMORNICKI, T. (1999). The development of international bus transport in Central Europe: The case of Poland. In Regular interurban coach services in Europe. ECMT Round Table, 114, Paris, pp.47-76.

Koncepcia transformácie a privatizácie štátnych podnikov Slovenskej autobusovej dopravy (no data), [Online], Available: www.telecom.gov.sk/index/index.php?ids=4451 [Accessed 12 October 2012].

LIBERADZKI, B. (2007). Koncepcja liberalizacji transportu. In: Liberadzki, B. ed. Liberalizacja $i$ deregulacja transportu $w$ Unii Europejskiej. Oczekiwania $i$ doświadczenia. Warszawa-Poznań (Instytut Logistyki i Magazynowania), pp. 39-46.

MACKIE, P., PRESTON, J. M, NASH, C. A. (1995). Bus deregulation: Ten years on. Transport Reviews, 15 (3), 229-251. 
MAJEWSKI, J., SZAŁUCKI, K. (1992). Zachowania przedsiębiorstw samochodowych w gospodarce rynkowej. Przeglad Komunikacyjny, 7-8, 23-25.

MENES, E. (2002). Stan i perspektywy rozwoju pozamiejskiego transportu publicznego w Polsce. Zeszyty Naukowe Instytutu Transportu Samochodowego, 92, Warszawa.

NELSON, J. D., SALEH, W., PRILESZKY, I. (1997). Ownership and control in the bus industry: The case of Hungary. Journal of Transport Geography, 5 (2), 137-146.

OLSSON, M. (1999). Ownership reform and corporate governance. The Slovak privatisation process in 1990 - 1996. Acta Universitatis Upsaliensis. Uppsala Studies in Economic History. Vol. 49, Uppsala (Uppsala University).

OPLETAL, J., RYBA, J. (1996). Case study: Czech Republic, privatisation and regulation of road freight transport. ECMT Seminar, Paris.

PALDA, K. (1997). Czech privatization and corporate governence. Communist and PostCommunist Studies, 30 (1), 83-93.

POLEWSKA-DOROZIK, H. (2001). Warunki funkcjonowania rynku pasażerskich przewozów drogowych. Przegląd Komunikacyjny, 10, 5-11.

PRILESZKY, I. (1993). Transport restructuring in Hungary. In: Hall, D. R. ed. Transport and economic development in the new Central and Eastern Europe. London-New York (Belhaven Press), pp. 93-107.

PRILESZKY, I. (no data). Directions in the economic regulation of public bus transport [Online], Available: www.heja.szif.hu/TAR/TAR-020905-A/tar020905a.pdf [Accessed 20 November 2006].

SAPIJASZKA, Z. (1997). Restrukturyzacja przedsiębiorstwa. Szanse i ograniczenia. Warszawa (PWN).

SCHNELL, M. C. A. (2001). Competition for the German regional rail passenger market 5 years after regionalization. Transport Reviews, 22 (3), 323-334.

SHAW, J. (2001). Competition in the UK passenger railway industry: Prospects and problems. Transport Reviews, 21 (2), 195-216.

SIMPSON, B. J. (1996). Deregulation and privatisation: The British local bus industry following the Transport Act 1985. Transport Reviews, 16 (3), 213-223.

SZAŁUCKI, K. (2003). Z doświadczeń nad kształtowaniem wartości rynkowej przedsiębiorstw transportu zbiorowego w procesie ich prywatyzacji. In: Dydkowski, G., Tomanek, R. eds. Liberalizacja transportu $w$ warunkach transformacji gospodarczej. Prace Naukowe Akademii Ekonomicznej im. Karola Adamieckiego w Katowicach. Katowice, pp. 189-193.

TAYLOR, Z., CIECHAŃSKI, A. (2007). Przekształcenia własnościowe przedsiębiorstw PKS w nowej sytuacji gospodarczej. Przeglad Geograficzny, 79 (1), 5-44.

TAYLOR, Z., CIECHAŃSKI, A. (2008a). Transformacja własnościowa przedsiębiorstw PKS po roku 1990. Przeglad Komunikacyjny, 4, 3-13.

TAYLOR, Z., CIECHAŃSKI, A. (2008b). What happened to the national road carrier in a post-communist country? The case of Poland's state road transport. Transport Reviews, 28 (5), 619-640.

TAYLOR, Z., CIECHAŃSKI, A. (2010a). Przekształcenia organizacyjno-własnościowe pasażerskich przedsiębiorstw komunikacji samochodowej. Transport Miejski i Regionalny, 2, 19-25.

TAYLOR, Z., CIECHAŃSKI, A. (2010b). Polskie przedsiębiorstwa publicznego transportu regionalnego i miejskiego w warunkach gospodarki rynkowej. Przeglad Komunikacyjny, 7-8, 20-25,

TAYLOR, Z., CIECHAŃSKI, A. (2017). Narodowi przewoźnicy drogowi w krajach Grupy Wyszehradzkiej - część II. Przegląd Geograficzny, 89 (2), 233-267. DOI: https:// doi.org/10.7163/PrzG.2017.2.3

TAYLOR, Z., CIECHAŃSKI, A. (2018). Systemic transformation and changes in surface transport companies in Poland: A synthesis after twenty-five years. Journal of Transport Geography, 70, 114-122. DOI: https://doi.org/10.1016/j.jtrangeo.2018.05. 016 
TEICHMANN, E. (1995). Deregulacja i liberalizacja a konkurencja w transporcie. In: Januszkiewicz, W. ed., Trans'95. Wspólna Europa. Szanse i zagrożenia dla transportu. Warszawa (SGH), pp. 337-349.

TYSON, W. J. (1995). Bus deregulation - the planning dilemma. Transport Reviews, 15 (4), 307-313.

VAN DE VELDE, D. (2013). Long-distance coach services in Europe. In: Finger, M., Holvad, T. eds. Regulating transport in Europe. Cheltenham, UK-Northampton, MA, USA (Edward Elgar), pp. 115-139. DOI: https://doi.org/10.1016/j.trpro.2017.05.428

WHITE, P. R. (1995). Deregulation of local bus services in Great Britain: An introductory review. Transport Reviews, 15 (2), 185-209.

WHITE, P. R. (1997). What conclusions can be drawn about bus deregulation in Britain? Transport Reviews, 17 (1), 1-16.

Websites

www.arriva.cz - official website of the Arriva holding Česká republika [Accessed 10 January 2013 and 20 April 2016].

www.infoveriti.pl - official website of the Infoveriti firm enabling access to Poland's KRS (National Registry) [Accessed 5 November 2013 and 1 December 2016].

www.kamin.sk - private website, including SAD companies [Accessed 9 January 2012 and 1 July 2012.

www.mnvzrt.hu - official website of the Magyar Nemzeti Vagyonkezelö (The Hungarian National Board of Assets) [Accessed 20 February 2016].

www.msp.gov.pl - official website of the Ministerstwo Skarbu Państwa (Poland's Treasury) [Accessed 15 July 2006 and 15 November 2016].

www.or.justice.cz - official website of the Obchodni rejstrík a sbirka listin (The Czech Republic Registry) [Accessed 30 October 2016].

www.orsr.sk - official website of Obchodnỳ register Slovenskej republiky (The Slovak Republic Registry) [Accessed 1 September 2016].

www.sadmi.sk - official website of the Slovenská autobusová doprava Michalovce company [Accessed 10 February 2012].

Zbigniew Taylor, Ariel Ci echańs $k i$

\section{TRANSFORMÁCIA VLASTNÍCTVA A PRIAME ZAHRANIČNÉ INVESTÍCIE V OBLASTI CESTNEJ VEREJNEJ DOPRAVY V KRAJINÁCH V4}

Ciel'om tohto článku je analyzovat' zmeny a poukázat' na všeobecné črty procesov súvisiacich $\mathrm{s}$ transformáciou vlastníctva a vstupom priamych zahraničných investícií (PZI) vo verejnej medzimestskej autobusovej doprave v krajinách V4 za ostatných 25 rokov (PKS v Pol'sku, ČSAD v Česku, SAD na Slovensku a Volán v Mad'arsku). Najdôležitejším faktorom $\mathrm{v}$ procese reštrukturalizácie, ktorý sa uskutočnil $\mathrm{v}$ tomto regióne, bol proces privatizácie vo vel'mi rozmanitých formách. Osobitnú úlohu zohrávajú aj PZI, predovšetkým vo forme investícií do pôvodných podnikov národných prepravcov (najmä v prípade najväčšieho investora zo skupiny Deutsche Bahn). Prílev PZI do krajín V4 bol sprevádzaný negatívnymi javmi, napr. odchodom niektorých investorov, bankrotmi a rušením spoločností. Napriek podobnej počiatočnej situácii u vnútroštátnych dopravcov poskytujúcich služby cestnej osobnej dopravy nadobudol transformačný proces v každej krajine vlastnú formu, výsledkom čoho je úplne iná súčasná situácia. 
V roku 2000 dominoval predovšetkým verejný sektor, avšak pre Pol'sko a Slovensko boli charakteristické najmä štátne podniky. Mad’arsko a Pol'sko tiež komercializovali spoločnosti prostredníctvom výhradných alebo takmer výhradných štátnych podielov v týchto podnikoch. V Česku bol v dôsledku realizovanej kupónovej privatizácie vysoký podiel súkromného vlastníctva. V Pol'sku bolo len málo súkromných spoločností (vznikli prostredníctvom zamestnaneckej privatizácie). Vo všetkých štátoch V4 existovala v tom čase iba jedna spoločnost' s PZI.

Do roku 2015 sa situácia výrazne zmenila. Pätnást'ročné obdobie prinieslo radikálny pokles počtu bývalých spoločností PKS v Pol'sku. Jedným z dôvodov tohto stavu je najsilnejšia liberalizácia. Väčšina pol'ských subjektov bola sprivatizovaná, hoci pomerne vel'a z nich zostalo vo verejnom vlastníctve. Podl'a názoru autorov ide o chybný prístup, ktorý má závažné sociálne a ekonomické dôsledky. Česko a Slovensko uskutočnili úplnú privatizáciu svojich spoločností. Privatizované spoločnosti boli obvykle na trhu ovel'a aktívnejšie a pôsobili dlhšie ako spoločnosti vo verejnom vlastníctve. Komercializácia je jedným z najbežnejších procesov transformácie, ktorý sa uskutočnil vo všetkých štyroch krajinách V4 (v Mad'arsku to bol jediný proces).

Priama privatizácia bola pomerne rozšírená aj v krajinách V4 (s výnimkou mad’arského Volánu). Najvýznamnejšiu úlohu v PZI zohráva nemecká spoločnost' Deutsche Bahn, predovšetkým prostredníctvom spoločností skupiny Arriva. Viacerí domáci vlastníci investovali do niektorých pobočiek. Relatívne vel'ká skupina predátorských investorov pochádzajúcich $\mathrm{z}$ finančného sektora a sektora nehnutel'ností (najmä v Pol'sku) sa zaujímala iba o aktíva týchto subjektov.

Česko je nepochybne lídrom v privatizácii prímestskej autobusovej dopravy, a to najmä vd'aka programu privatizácie, ktorým sa procesy transformácie vlastníctva začali a ukončili najskôr a s najväčším úspechom. Privatizačné procesy na Slovensku a v Pol'sku sa začali až po tom, ako sa v Česku dokončili klúčové zmeny vo vlastníctve tejto časti trhu s cestnou verejnou dopravou.

Article first received: September 2019

Article accepted: March 2020 